\title{
CRIMEAN TURKISH KARAIM AND THE OLD NORTH- WESTERN TURKIC TRADITION OF THE KARAITES
}

\author{
HENRYK JANKOWSKI \\ Adam Mickiewicz University in Poznań \\ al. Niepodległości 24, 61-714 Poznań, Poland \\ e-mail: henryk.jankowski@amu.edu.pl
}

\begin{abstract}
The aim of this paper is to examine the language of Karaite literature, mostly translations from Hebrew, developing in the 18th-19th centuries in the Crimea. Linguistic features of most works of this literature are typical of Crimean Turkish with many North-western Turkic or Kipchak properties. Among the most important authors and translators there were such distinguished intellectuals and spiritual leaders as Abraham Firkovich, Joseph Solomon Łucki, Abraham Łucki, Mordecai Qazaz, and Eliyahu Qazaz. Because of the mixed character of this language and the lack of strict standards, its definition and attribution is still debated. Until all works will be examined, it seems reasonable to speak of the individual language preferences of some leaders who created and practised it, rather than of the literary language of Crimean Karaites in general.
\end{abstract}

Key words: Turkish Karaim, Crimea, Turkey, Karaite intellectuals.

\section{Turkic Languages of the Crimean and Turkish Karaites}

There are various opinions of the language of Crimean Karaites (Karaims). Radloff (1896, p. xvi) claimed that it was identical to Crimean Tatar or Crimean Turkish according to the region they inhabit. This opinion was shared by Doerfer (1959a, p. 273, 1959 b, p. 369). Musaev regarded the language of Crimean Karaites as fully assimilated to Crimean Tatar and did not include it in his grammars of Karaim (Musaev 1964, 1977, 2003). Pritsak (1959, p. 321), although he stressed that Crimean Karaim is unexplored and therefore paid little attention to it in his article, observed that Crimean Karaim was closely related to Troki Karaim. Radloff's opinion was first contested by Samojlovič in 1917 who stressed methodological mistakes committed by Radloff. Samojlovič said that much of the material recorded by Radloff does not represent Karaim literature and the available historical texts demonstrate that their language was older and different from Crimean Tatar (Samojlovič 2000, pp. 116-119). 
Two quite different opinions were pronounced in 2003. In Jankowski (2003) it was argued that the Crimean Karaites used a few language variants through the centuries. They certainly communicated with their overlords in Crimean Tatar or Turkish which was the most prestigious language in the Crimea or at least tried to adapt their Turkic language to Crimean Tatar and Turkish as was needed in a communicative situation. The Turkic language of their religious literature was also generally adapted to the current trends in the language use in the Crimea, though the translations of the Bible, which was the basic canonical literature of the Karaims, were more resisting to change. The secular folk literature also followed the basic trends in the Crimea. Popular literature is best known from the handwritten books called mejumas (Jankowski 2003, pp. 116-119).

In contrast, Shapira (2003, p. 662) denied the very existence of Crimean Karaim and claimed that such a language had never existed. Like Radloff and Doerfer he argued that the Crimean Karaites spoke the language of their Muslim and Christian neighbours and the Karaim texts known from the Crimea were in fact composed in the West and only copied in the peninsula. The arguments against this claim will be shown below.

Kipchak Karaim in the Crimea is first attested in the 18th century, though it certainly existed much earlier, as the archaic features of Bible translations from the Crimea demonstrate.

Our knowledge of the Turkish spoken by the Karaites in Turkey is even more limited. All we know are two short fragments of Turkish hymns from the 16th century in a Venice prayer book, the translation of the Pentateuch into Turkish printed in $1832-1835$, though initiated by Abraham Firkovich from Łuck who migrated to the Crimea, ${ }^{1}$ and the translation of the Book of Obadiah, known from a 19th-century manuscript (Shapira 2014).

The first two 16th-century fragments are especially valuable and it is worth presenting them here. These fragments were included in the Karaite Hebrew prayer printed in 1528/1529 in Venice. Information about this publication was first delivered by Poznański (1913, p. 40), but he could not see the original printed book and referred to its later edition in Qale of 1741, titled Seder berakot (the date of publication was provided as 1742, but in his later article, see Poznanski 1918, p. 42, it was shown as 1741). Poznański pointed to two short Turkic fragments, one being hymn 92 in Hebrew and "Tatar" (hebräisch und tatarisch), the other being hymn 140 which he said was only "Tatar" (nur tatarisch abgefasste). Poznański quoted both relevant Turkic texts in Hebrew script. In the original Venice publication ${ }^{2}$ the first fragment was wrongly set by a Jewish typesetter who did not know Turkish, and it was not corrected in the

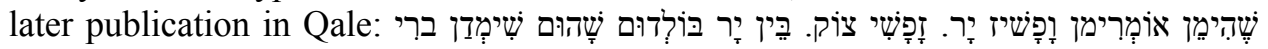
This text should be reconstructed as:

\footnotetext{
${ }^{1}$ Another printed book that appeared in Turkey came into being due to the efforts of Joseph Solomon Łucki, see below.

${ }^{2}$ This text was found on page 380 , volume IV, available online at http://jnul.huji.ac.il/d1/ books/djvu/1103403-4-5/index.djvu?djvuopts\&thumbnails=yes\&zoom=page). My thanks go to Prof. Piotr Muchowski for sharing this link with me.
} 
(1) Şahımın, ömrimin vafasız yar, safası çok. Ben yar boldum, şahum, şimden beri 'Disloyal friend of my king, of my life, he enjoys much pleasure. O my king, I have become a friend.'

Hymn 140 (volume IV, 212) is in fact composed in Greek, only the refrain being Turkish Karaim: ${ }^{3}$

(2) Ibadetlen baş urarım, şu 'alemi yaradana; bir münazi ' padişahdır, karar olmaz aklına; evvel ahır ol gendidir, kimse ermez sırına; ancak ki az şefa atın eyler ese kuluna

'I bow in prayer in front of the Creator of this world; no ruler may be equal in wisdom to Him; He is the beginning and the end, nobody can understand His secret, unless He Himself shows mercy upon His servant.'

The question of the original language of the Karaites and their ethnicity will not be discussed in this paper. However, it is worth stressing that the Karaites most probably migrated to the Crimea from the Byzantine Empire after escaping Jerusalem in the aftermath of the Crusades and that their first homeland where Karaism emerged was the Abbasid Caliphate. ${ }^{4}$ Therefore, the most likely chain of their spoken languages is Arabic $\rightarrow$ Greek $\rightarrow$ Kipchak Turkic $\rightarrow$ Crimean Turkish $\rightarrow$ Russian.

As far as their written language is concerned it must be said that the role of the language of religious literature, community administration and personal correspondence was fulfilled by Hebrew as long as the Karaite religion existed in the traditional form, even long after the separatism from Judaism. Turkic literature of the Karaites was supplementary to Hebrew in all areas.

Three papers have been devoted to the literature of Crimean Karaites so far, Poznański (1913), Šapšal (1918) and Jankowski (2012). Information can also be found in other studies, e.g. Zajączkowski (1926, pp. 7-17, 1964, pp. 793-801), Dubiński (1960, pp. 145-156), Shapira (2003, pp. 657-707), and Aqtay (2009, pp. 23-28).

In Jankowski (2012, pp. 57-61) twenty-eight works were demonstrated, both printed and manuscripts. They include all kinds of literature, religious, translations from folklore and belletristic works, handbooks and textbooks, and occasional papers. This list is not by far complete. It was noted that there is a need to examine the contents of many extant manuscripts called mejumas in which new works will certainly be found..$^{5}$ For example, in addition to three theatre plays quoted in items 26-28, i.e. Ahab, Izebel and Melukat Ša'ul, we should add the biblical drama called Tiyatir 'im targum Iša 'iya 'Theatre (play) with translation of Isaiah' was identified in a mejuma owned by Solomon Asaba (Jankowski 2013, pp. 255-256).

${ }^{3}$ Zajączkowski (1926, p. 8; 1961, p. 89; 1964, p. 793) mistakenly defined this short fragment as "Kipchak-Karaim", which was corrected by Shapira (2003, pp. 691-692), more for this see Aqtay (2009, pp. 19-20) and Jankowski (2012, pp. 53-54).

${ }^{4}$ The Khazar theory put forward by some scholars (Šapšal, Zajączkowski) has been proved neither historically nor linguistically.

${ }^{5}$ Moreover, the list does not include a few poems and dramas published by Crimean Karaites in Cyrillic script by such writers as Levi and Qatıq. 
In the discussion of the Karaim languages and the attribution of a work to a language, a few restrictions should be made. Firstly, it is possible that a written work was linguistically changed or modified by a copyist. Secondly, language features cannot be established on geographical principle. In other words the fact that a book was written or published in Turkey, the Crimea or in Vilna does not necessarily mean that it was in Turkish Karaim, Crimean Karaim or Western Karaim, respectively. ${ }^{6}$ For example, as was demonstrated in Jankowski (2012, p. 68), the prayers Targum selihot of 1734 printed in Qale are translated into an archaic Crimean Karaim language, see below, while Isaac Sultanski's ${ }^{7}$ translation published in Vilna in 1892 is Turkish Karaim:

(3) Adonaj Tayrymyznyydyr ol raximlár da ol bašatlyqłar ki tandyq ayar (1734) ${ }^{8}$

(4) Adonay Tañrımızıñdır ol rahimler ve ol 'afu idmekler farzam ki assi olduk da ise oña (1892)

'The mercy and forgiveness belong to our Lord God whom we defied'.

Thirdly, we should not trust in such labels as "Tatar" or "Karaim". We can see how misleading it is from the case of a booklet called Molad qarayïmča 'Calendar in Karaim', present among nineteen pieces of Turkic literature in Poznański (1913, p. 43), which - as Poznański and Jankowski (2012. p. 56) demonstrated - is in Russian.

The attempt to create a national Karaim language should be linked to some external circumstances in the life of the Karaites. Such a circumstance is certainly the establishing of the Turkish printing house in Istanbul by İbrahim Müteferrika and the first known printed books in the 1720 s. ${ }^{9}$ This event is related to the attempts of the first reforms in Turkey during the so-called Tulip Period 1718-1730, but probably also to the reforms in Europe, and in Russia during Tzar Peter I.

\subsection{Crimean Kipchak Karaim}

We know only three types of texts written in Crimean Kipchak Karaim. The first is the aforementioned translation of the prayers for forgiveness called Targum selihot in the first Karaim book printed in the Crimea in 1734 Sefer ha-haftarot $u$-še 'ar haddevarim ham-mequbbașim [...] Meqabbeș nidhei Yisra'el, probably translated, adapted

\footnotetext{
${ }^{6}$ This was often the case with Poznański's bibliographical descriptions who qualified the publications printed in Turkey Turkish and those from the Crimea Tatar. However, Poznański should not be blamed, for he admitted his incompetence in Turkic languages and his bibliographical contributions are invaluable. In practice, however, all later contributions (Zajączkowski 1926, Walfish 2003, Jankowski 2012) are largely based on Poznański's articles.

${ }^{7}$ According to El'jaševič (1993, pp. 181-182), Isaac Sultanski (1824-1899) was the son of Mordecai Sultanski who came to the Crimea from Łuck. Isaac was said to be a teacher in the religious school who raised many pupils and authors of many translations into Karaim of which all were lost except one mentioned here.

${ }^{8}$ Sulimowicz's transcription has been retained.

${ }^{9}$ According to Poznanski (1918, pp. 35-37), the first three Karaite books published in Istanbul appeared in the 16th century, but they were written in Hebrew.
} 
or initiated by Simha Isaac Łucki, edited by Sulimowicz (1972, 1973). According to Shapira, these prayers are copies from the Łuck manuscripts (2003, p. 693).

The second is the translation of the Passover Haggadah, Targum hallel haqqațan, published in Gözleve (present-day Eupatoria) without date and the name of the translator (Poznański 1913, p. 46). Unfortunately, this publication was unavailable and I only know one verse of it (being Psalm 71:16) quoted by Poznański in Hebrew script and provided in a transcription in Jankowski (2012, p. 60):

(5) Keleyim bă̆atırlıqlar bilen, ey Adonay Tañrı; să̆ındırayım dŏ̆ruluğuñnı yal̆̆ız özüñnü̃

'I will come courageously, O Lord God; I will make mention of your righteousness, of yours only'.

The third type of Crimean Kipchak Karaim literature are Bible translations, preserved in many manuscripts (Jankowski 2009, p. 507) and also known from the printed edition of the whole Bible of 1841 in Gözleve. The oldest extant manuscripts originated from the 18th century, although they were copied from much older translations. Only one manuscript of this type has been edited so far in fragments (Jankowski 1997). Another manuscript of the whole Bible except the Chronicles is found among the holdings of the University Library in Cambridge (Jankowski 2009, p. 506). ${ }^{10}$ The translation of this manuscript is very similar to the 1841 Bible $^{11}$ (Poznański 1913, p. 45; Poznanski 1920, pp. 65-66). As for the latter, we know the name of a copyist who copied the Books of Prophets and Hagiography. He is Jacob b. Mordecai, who died in Qale in 1701, and who completed the copy in 1672 (Poznanski 1916, p. 88); according to Shapira (2003, pp. 696-697), he completed the translation or the copy of the Book of Nehemia in 1632 or 1634. Shapira (2013, pp. 157-160) has identified the grave of the copyist in the cemetery of Qale, but his claims that he was an immigrant from the West are not convincing. The Bible published in 1841 is still little known. There are only some short fragments quoted from it and discussed in various studies, the first more detailed discussion and a transliteration of Nehemia being presented in Shapira (2013, pp. 181-187).

Crimean Kipchak Karaim is relatively uniform. We encounter similar forms in most manuscripts of biblical translations. In the following, we shall present some typical North-western or Kipchak Turkic features of this language. In phonology, roundedunrounded vowel harmony has some restrictions, e.g. qoygï 'put'; lenition of strong stops $q k p$ is frequent in verbs between vowels, e.g. čigar- 'to push out, but not $t$, e.g. etär '(he) does'; initial $t$-, $k$ - and $b$ - in bol-, bar-, ber-, bar are mostly preserved. Among noun case suffixes we see the genitive $-n I \eta$, the accusative $-n I$, and the dative $-G A$. From verb suffixes we can point to the imperative -QIn, subjunctive - $Q A y$, such actional forms as qümilday turgan '(he) is moving', for notes on phonetics see Sulimo-

${ }^{10}$ There are many other manuscripts with Bible translations from the collection of the former Qaray Bitikligi, founded by Šapšal, now at the Institute of Oriental Manuscripts of the Russian Academy of Sciences in St. Petersburg, formerly Institute of Oriental Studies. They are shown in the bibliography in KRPS (pp. 28-29).

${ }^{11}$ Also without the Chronicles. 
wicz (1972, p. 46), for a short grammatical description see Jankowski (1997, pp. 7 25); for the vocabulary, in addition to the afore-mentioned articles, see Gordlevskij (1928, pp. 88-90).

However, since many manuscripts were written or copied long after this language was adapted to Crimean Tatar and Crimean Turkish, the translators inevitably changed old forms with new ones, for the examples see Jankowski (1997, pp. 9, 24).

If we compare the language of these texts with the language of the contemporary Western Karaim as shown by Jankowski (2014) and Németh (2014) for Northwestern Karaim and Németh (2011) and Olach (2013) for South-western Karaim, we see that - although both Western and Eastern Karaim were very similar then - there are no typical Western Karaim features such as oltur- 'to sit; to dwell' (CKKar otur-), ošol 'that over there' (CKKar šol, Olach 2013, p. 78), -billa -bile 'with' (CKKar bilän) or -dogač 'when ...' in the Crimea.

\subsection{Crimean Turkish Karaim}

In contrast to Crimean Kipchak Karaim, Crimean Turkish Karaim is less standardised. This is because the former went through an old literary tradition, whereas the latter is attested in a relatively short period of time when the writers were trying to establish a literary norm.

In the domain of phonetics and phonology, initial $t$-, $k$ - normally $\rightarrow d$-, $g$ - and bol-, bar-, ber-, bar $\rightarrow$ ol-, var-, ver-, var; lenition of $q k p$ in verbs between vowels does not normally occur, but lenition of $t$ in some verbs does, as in standard Turkish, e.g. eder '(he) does'. Noun case suffixes are most variable, they can be, like in Crimean Kipchak Karaim, mixed with South-western forms, or predominantly Southwestern, i.e. the genitive $-n I \eta$ only after a vowel, the accusative $-(y) I$, and the dative $-(y) A$. Verb suffixes are almost entirely South-western with such typical forms as perfect $-m I \check{s}$, sometimes progressive $-y U r$-. The postposition bilän 'with' was replaced with ilen, kibik 'like; as' with gibik.

The lexicon of Crimean Turkish Karaim is also quite different from Kipchak Karaim. Some characteristic North-western words were replaced with South-western ones, e.g. köp 'much, many' with čoq; ešik 'door' with qapu; yašir - 'to hide' with gizle-, some with Arabo-Persian words typical of Turkish, e.g. ulus 'nation' with millet, kerti 'truly' with h̆aqqa etc.

However, some specific words and forms are evidenced only in the Crimea and are known in neither Western Karaim nor Turkish, e.g. oturaş 'residence; dwelling (place)', cf. HKar. otturus 'krzesło, siedzenie | Sitz, Stuhl' (Mardkowicz 1935, p. 52), TKar. olturuš 'id' (KRPS, pp. 427-428); hüsste 'well', cf. Tur. işte.

In the following, some typical irregularities and deviations from the norm will be shown. In phonology, there are such features as (1) incidental retention of $b$ - in bol'to be, to become', ber- 'to give', bar- 'to go', bar 'there is'; (2) incidental retention of $t$-, e.g. tur- 'to stand'. In morphology, there is (1) frequent use of North-western postpositions, e.g. uçun, birge, soñ, incidentally bilen; (2) use of the participle and past -QAn, 
e.g. vergen 'gave', qoyğan 'put'. In lexicon, some North-western words such as keñeş 'counsel', orun 'place', burun 'before', burunğl 'being before' and maxta- 'to praise' frequently occur. Incidentally Crimean Tatar words such as cayav 'on foot', cuvur'to run' are also encountered.

It should be noted that Crimean Turkish was different from contemporary Standard Turkish. We shall point to some typical differentiating features below. In phonology, (1) $t-\rightarrow d-; k-\rightarrow g$ - in those words in which this change has not taken place in Standard Turkish, e.g. tut- $\rightarrow$ dut- 'to hold, to grasp', taş $\rightarrow$ daş 'stone'; kendi $\rightarrow$ gendi

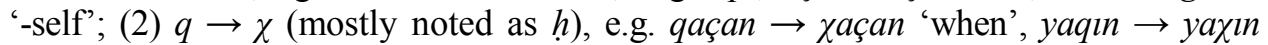
'near'. In morphology, there are: (1) use of the converb -DIQçAz, e.g. bir işi duttıqçaz Haq kerimdir | gériye qalmaz meclisde bulunmadıqçaz (Aqtay 2009, p. 203) 'God will be gracious as long as we do anything | there will be nothing without us until we do not join the meeting'; this converb is not mentioned by Doerfer (1959a), but it is present in some isolated Turkish dialects, e.g. that of Rize (Günay 2003, p. 186); (2) use of the converb -InçAz, e.g. ölünçez 'until (I) live' (Aqtay 2009, p. 45); (3) use of the converb -(y)AndA, e.g. ben mektebde oquyanda (Aqtay 2009, p. 94) 'when I was studying at school'; (4) present or progressive -AyIr, -Uyır, e.g. baqayırım 'I am looking', gelmeyirsiz 'you are not coming', duruyır '(God) is standing' (Aqtay 2009, pp. 37-38).

\section{Language Preferences of Crimean Karaim Intellectuals and Spiritual Leaders}

The Karaite population in the Crimea was always low in number, according to Kupoveckij's estimates (1983, p. 77), it amounted to approximately 2600 in 1783 . The most influential figures who formed the linguistic attitudes were teachers (erbi) and spiritual leaders (hazzan), later also publishers. ${ }^{12}$ Karaim was not a language of study, but a language to which pupils were taught how to translate Hebrew canonical and liturgical literature. It can be assumed that Karaim was also the medium of instruction through which young Karaites studied Hebrew. Quite interestingly, many teachers, spiritual leaders and publishers ${ }^{13}$ were not Crimean, but western Karaites, mostly from Łuck. One of the first known Karaite sages who migrated from Łuck was Simha Isaac b. Moses Lucki (died 1761 or 1766 in Qale). They had to decide which language and which standard may be the most suitable for the Karaites. The most essential aspect was the question which variant of Turkic was the best for all communities, Western Karaim, Crimean Karaim or Turkish. After Russia had brought a kind of integrity to the Karaite communities in Lithuania, Wolhynia and the Crimea at the end of the

${ }^{12}$ However, it is to be noted that the first Karaim printing house established by Isaac Sinani in Qale (1734-1741) was operated, among others, by the printers brought from Turkey, namely Afeda and Shabbetai Yeraqa (Poznanski 1918, p. 39).

${ }^{13}$ We know at least three Karaim printing houses that worked in Gözleve between 1833 and 1914 with some interruptions, owned or operated by Mordecai Tırışqan, David Kukizov (17771855) and Abraham Firkovich (El'jaševič 1993, p. 189, Jankowski 2012, p. 55). 
18th century, the most useful was Turkish which was spoken by all educated people in the Crimea, but was also comprehensible to the Western Karaite intellectuals. Another reason for choosing Turkish in its Crimean variant as a common language for the Turkic-speaking Karaites was Abraham Firkovich's interests in the Middle East and Turkey. ${ }^{14}$ Shapira (2013, p. 174) considers this language to be "an artificial and mixed half-Łuck-Karaim / half-Constantinople-Turkish vernacular". Shapira is certainly right when he stresses Firkovich's impact and a kind of artificial character of this language, but we cannot agree with some details. Firstly, as the linguistic features of the publications printed in Turkey and initiated by Firkovich (Zeker rav, Šoreš davar, Petah hat-teva', the Pentateuch of 1832-1835) show, there is hardly any Łuck Karaim stratum in the language, which in addition is not uniform; the language of the Pentateuch is undoubtedly Turkish Karaim which we can term "Karaeo-Turkish"15 with very few North-western features; the language of Zeker rav, Šoreš davar, Petah hat-teva' is mixed. Even the language of Firkovich's another translation, Kelalei hadiqduq bi-lešon Qedar, is different from the 1832-1835 Pentateuch translation, see below. Secondly, as the specialists of Crimean Tatar and Crimean Turkish demonstrate (e.g. Doerfer 1959b, p. 371), all Crimean dialects were mixed and contained both South-western and North-western elements, which was a very favourable circumstance to create a "mixed" language for the Turkic-speaking Karaites. Another point which must be modified in Shapira's statement is that Crimean Turkish is not based on the dialect of Istanbul (see such forms as daş, gendi, geliñiz, ilen).

It is still a question to answer if the efforts of Abraham Firkovich and his followers can be considered what modern linguistics terms language planning and language policy or just their individual endeavours to develop education and literacy. The answer to this question needs further examination. It is possible that some Karaite intellectuals, being aware of lexical and structural differences between Standard Ottoman Turkish, Crimean Turkish and Crimean Tatar, just tried to create a middle standard that would incorporate some North-western features into Turkish and used Turkish in a simple variant without Persian syntactic structures and sophisticated Ottoman lexicon. It is hard to tell if the North-western elements that they transferred into Turkish were employed purposely or unintentionally. Since the local Turkic languages in the Crimea were not codified, but regulated by tradition and common consensus, the writers, editors and publishers were not compelled to any strict regulations, as was needed in the case of Hebrew.

The selection of Crimean Turkish as a common language was also optimal because the Crimea was in a way central and the most populated region by the Turkicspeaking Karaites. However, there were a few problems. One was the competence of western intellectuals in Turkish. The fact that they all understood Turkish does not imply that they could use it perfectly in writing and translate Hebrew literature into it.

${ }^{14}$ Abraham Firkovich's inclination to Turkey and Turkish probably started with his first travel to Turkey and the Middle East in 1830 (Harviainen 2003, pp. 878-879) where he stayed until 1832.

${ }^{15}$ For the term "Kareo-Turkic" see Wexler (1983, p. 29). 
Unfortunately, we do not have access to documents showing the linguistic views of the creators of Karaim literature, whereby conclusions will be drawn basing on linguistic features of their works. In the following we present some titles of the Turkic works - mostly translations - of the following prominent Karaite intellectuals: Abraham Firkovich, Joseph Solomon Łucki (Yašar), Abraham b. Joseph Solomon Łucki (Aben Yašar), Mordecai Qazaz, and Eliyahu Qazaz with short samples, wherever possible.

\section{Abraham Firkovich ${ }^{16}$}

1. Translation of the Pentateuch with the parallel Hebrew text (Istanbul, 1832-1835), carried out by Abraham Firkovich, Simha Egiz and Isaac b. Samuel Kohen (Poznański 1913, p. 45, Walfish 2003, p. 935, Shapira 2003, p. 695, Jankowski 2012, p. 58). ${ }^{17}$ The language of this translation is typically Turkish, the most similar to Standard Turkish from all Karaim works analysed, but even in it there are some Kipchak elements indicated in Jankowski (2009, pp. 514, 516), e.g. Yeli Tañrınıñ 'the Spirit of God', yarıq 'light', suv 'water'. In the samples quoted below there is an occurrence of the suffix -nIñ after a consonant, Yarden'nin 'of Jordan'.

Samples:

Gen 6:10 Da doġurdu Novah üç ogglanlar (p. 21) 'And Noah begat three sons'.

Exod 1:1 Bunlar adlart evladlarının Yisra 'el'in ol gelenler Misır'a Ya 'qub ilen her kişi da evi geldiler (p. 178) 'These are the names of the children of Israel who came to Egypt; every man and his household came with Jacob'.

Lev 1:1 Da çaġırdı Moşe'ge ohel mo 'edden da sevledi H ona deme (p. 327) 'And the Lord called unto Moses, and spoke unto him out of the tabernacle of meeting, saying'.

Num 1:2 Sayını sayımın cümle cema'atının evladlarının Yisra' el'in soylarına evine babalarının hesabı ilen (p. 439) 'You shall calculate the number of all communities of the children of Israel according to the number of families and households of your fathers'.

Deut 1:1 Bunlardır o cevablar ki söyledi Moşe cümle Yisra 'el'e beri yaqasında o Yarden'nin beriyede sehrada (p. 588) 'These are the words ${ }^{18}$ which Moses spoke unto all Israel on this side of Jordan in the wilderness'.

${ }^{16}$ Abraham Firkovich (1787-1874), a well-known Karaim scholar "of a mediaeval type", born in Łuck, was invited to the Crimea in 1822. There is much literature on him, see e.g. Harviainen (2003).

${ }^{17}$ The translator of this Pentateuch is unknown (Poznanski 1918, p. 71). It may be assumed that most work was done by those correctors who placed their names in the acrostics added to the publication, i.e. all three in the Genesis, Abraham Firkovich in the Exodus, Isaac ben Samuel Kohen in the Numbers, and Abraham Firkovich in the Deuteronomy, Leviticus being without any acrostic.

${ }^{18}$ Lit. 'the answers'. 
2. Iggeret tešu 'at Yisra'el 'Testimony of freeing the Israelites' (Gözleve, 1840), Firkovich's translation of Joseph Solomon Łucki's work (Poznański 1913, pp. 41-42, Poznanski 1920, pp. 66-67, Shapira 2003, p. 696, Jankowski 2012, p. 59).

3. Kelalei ha-diqduq bi-lešon Qedar 'Grammar in the Karaim language', a grammar of Hebrew (Gözleve, undated, probably 1840), (Poznański 1913, p. 43, Poznanski 1920, pp. 64-65, Zajączkowski 1926, p. 11, Jankowski 2012, p. 59). Walfish's "Karaim (Euck dialect)" (2003, p. 939) language assignment in the light of the sample below must be inexact. Like Firkovich's other works in Turkic, this is Crimean Turkish Karaim with some Kipchak features, basically noun case suffixes.

Sample:

Yod hireqlen niqudlenmekten gayrı tenu alarin birilen geldikte o yoddan evvel gelen şevaniñ oquması tebdil olur da hireqniñ oqumasina beñzer, mesela [...] 'If a shwa comes before the vocalised yod except for a hireq, the pronunciation of it changes to the pronunciation similar to a hireq, for example [...]'. This printing was unavailable and the sample is a transcription from a short fragment quoted in the Hebrew alphabet by Harviainen, formerly published in Jankowski (2003, p. 117).

\section{Joseph Solomon Lucki (Yašar) ${ }^{19}$}

1. Zeker rav ${ }^{20}$ 'The memory of the great' (cf. Psalm 145), printed in Istanbul in 1831, translation of a Hebrew story by Benjamin Musafia of the creation of the world (Poznański 1913, p. 43, Jankowski 2012, p. 57). According to Poznański and Walfish (2003, p. 935), it was intended as a textbook for schoolchildren. The language is predominantly Crimean Turkish Karaim with many Kipchak elements.

\section{Sample}

Sensen ol yalıñız bir, tek yaliñz sen da yoqtır senden başqa. Önce seniñ bilen da yoqtır yat birgeñe. Evvel yarattin evvelden da burundan günde ol burunğl da ilkinde sebebi uçun adiñniñ. Gendiñ uçun habar vermek qadirliğiñni ve qudretiñni. Verandan boşdan hiçden yoqdan nemeden degil varniñ gendisini ve halqni da binyat ittiñ (11) 'You are only one and there is no one else apart from You. There is no other beside You. It is You who created and brought about (the heavens and the earth); the first day and the beginning is due to Your name. It is up to you to proclaim your power. You formed the universe and mankind from voidness, nothing and nihility'.

${ }^{19}$ Joseph Solomon Łucki, known under his pen name Yašar, was born in Łuck in 1768, and died in 1844. He moved to the Crimea in 1803 where he acted as the teacher and counsellor of Solomon and Simha Babovich (El'jaševič 1993, pp. 126-130). He published and probably personally adapted various works which appeared together with Zeker rav in one volume.

${ }^{20}$ Pages 1-96; there are three different works with separate pagination published in one volume. 
This text is incomprehensible without the basic Hebrew text. For example, Sensen ol yaliñz bir is a literal translation of Heb. אַתָה הוּא יָחָיד אֶדָד 'You are unique and one'.

2. Šoreš davar 'The roots of words' (Istanbul, 1831), published in one volume with Zeker rav with separate pagination (pp. 1-342); this work is basically in Crimean Kipchak Karaim, though with many Turkish phonetical adaptations; according to Shapira (2003, p. 695) the language is "Tatarized and Turkicized Karaim" and the author of this work is Abraham Firkovich.

Sample

Yıltırmă̆l qulıçnıñ 'the flashing of your sword'; da büyük boldllar öktemligi gibi tütünnin 'the pride of the smoke has grown great' (p. 1).

3. Turkish translation of Sefer tohakot musar with the Turkish title Nesi at terbiyye 'Teaching good manners' (pp. 18-21), published in one volume with Zeker rav under the general name Hamșa'a hadaša midbar sin in the part titled Petah hat-teva'. The text of Nesi at terbiyye is provided in two columns, the right column contains the original Hebrew ( ivri), the left one the Turkish (turqi) translation. The language is Crimean Turkish Karaim with many Kipchak elements.

Samples:

Sevle dayım dogru, hiç bir vaqut yalan sevleme, zira sen insann aldatmaq elinden gelse de, lakin Allahı hiç olmaz (p. 19) 'Tell always the truth, never tell lies, since you can deceive man, but you cannot deceive God'.

As can be seen, the Turkish of this sentence, which is the beginning of the respective text, is quite clumsy.

4. Petah hat-teva' 'The gates of the nature' and other texts (pp. 21-56). This part of the publication which also contains the item above is composed of various short texts. One is the principles of the religion of which a short fragment will be shown below. The language is Crimean Turkish Karaim.

Samples:

Yisrael dinine mutllq on temel 'Ten absolute principles of the Israeli religion'

1. Ben ınandım tamam inamlıq ilen ki vardır Allah bir evvelki da ömürlük. Gendi gendini yaratdl ve ğayr kimseden dahl yaradılmadl. Aslından var edi ve şimdi dahl var ömürdek olur (p. 26) 'I have believed with my full belief that there is one God, from the very beginning and he will be forever. He has created himself and has not been created by anybody else. He existed from the origin, he exists at present and will exist forever'. 


\section{Abraham b. Joseph Solomon Lucki (Aben Yašar) $)^{21}$}

1. Abraham Łucki's introduction to Pinnat yiqrat 'Precious cornerstone', cf. Isayah 28:16 (Gözleve, 1834) to the work of Isaac b. Solomon of Qale, see Poznański (1913, p. 44; 1920, p. 67).

2. Mišlei musar 'Moralistic stories' (Gözleve, undated), see Poznański (1913, pp. 43-44, Walfish 2003, p. 939); according to Shapira (2003, p. 696), the author of this work is Joseph Solomon, Abraham's son. As for the language, Poznański (2003, p. 939) calls it Tatar and Walfish "Karaim (Luck dialect)", which is unlikely owing to the fact that Abraham's Łucki's another translation, Melukat $\breve{S} a$ 'ul, see below, is Crimean Turkish Karaim. ${ }^{22}$

3. Melukat Ša 'ul 'Shaul's kingdom', the translation of a historical Hebrew drama by Joseph Tropalovitz into Crimean Turkish Karaim; identified in a manuscript in Eupatoria dated 1875 or 1876 , shelf number VI-3/22. The critical edition of this drama, written in Crimean Turkish Karaim, has been prepared by Smętek (2012).

\section{Sample}

(Şaul) Daḥa qaḥarım yüregimde alevli ateş gibi yanayır. Bu 'Ameleq qavmunı qırdığımdan sonra, dahı rahatlıq bulamayırım. Milletim Mısır'dan çıqtıqları vaqıt onlara hasımlik göstürücüni '(Saul) The anger is still burning in my heart like a flaming fire. Even after destroying the tribe of Amalekites I cannot find peace of mind. When my nation was leaving Egypt, (Amalekites) acted hostile towards them' (quoted from Smętek 2012, pp. 104-105, with her translation into English).

\section{Mordecai Qazaz ${ }^{23}$}

1. Suf devaš 'Honeycomb’ or Balniñ solă̆l (Gözleve, 1935); a poem inspired by the Pentateuch, printed together with two other works (Poznański 1913, p. 44, Walfish 2003, p. 939, Jankowski 2012, pp. 56, 58). The language is a blend of Crimean Kipchak Karaim and Turkish.

\section{Sample}

Yarattıñ dünyanı yoqdan | Yerni kökni canlarnı | Cennetni ve cehenemni | qaranğulıqnı ve o nurnı | Malahları kavodları | Ol 'aziz dünyalarnı | Comartlı̆̆ıñnıñ çoğundan | İhsan edüp qulmışsın 'You have created the world from nothing; by your generosity,

\footnotetext{
${ }^{21}$ Born in Łuck 1793, died 1855 in Ekaterinoslav (El'jaševič 1993, p. 125).

${ }^{22}$ Even if we suppose that the copyist has changed some forms, it is very unlikely that he could completely convert it into Turkish from South-west Karaim.

${ }^{23}$ Died 1835 in Qale. According to El'jaševič (1993, p. 85), beyond the two works shown here, he also wrote a Hebrew grammar and a catechism.
} 
you have endowed us with the earth, the heavens and the living creatures; with the paradise and the hell; with the darkness and the light; with the angels and the dignities; with these nice worlds'. This initial fragment is quoted from manuscript A 126 (fol. 5a) held at the Institute of Oriental Manuscripts, St. Petersburg.

2. Tuv ța 'am 'Good taste' (Gözleve, 1935); a catechism, printed together with two other works (Poznański 1913, p. 44, Walfish 2003, p. 939, Jankowski 2012, p. 58). The language is Crimean Turkish Karaim with a few Kipchak features.

\section{Samples:}

(Question 4:) Sen hangi milletensin ve diliñ hangidir? 'What is your nationality and what is your language?' (Reply:) 'Ivri toqumındanmın, Avrahamnıñ oğlı Iç̧aq, Içhaqniñ oğlı Ya'qov, Ya 'qovniñ evladlarındanmin 'I am a descendant of Hebrews, from the offspring of Jacob, Isaac's son, the son of Abraham'. Milletime Israel derler ve dilimiz leşon qodeşdir 'My nation is called Israel and our language is the Holy Language' (fol. 1b).

3. Adam oğlu 'Man's son'; a short moralistic poem, attributed by Šapšal to Mordecai Qazaz, copied in the mejuma published by Aqtay (2009, pp. 102-113); a poem inspired by the Pentateuch. Despite some suppositions, it probably has never been published and the researchers could confuse it with another work shown by Poznański (1913, p. 44), see Jankowski (2012, pp. 56, 58). The language is Crimean Turkish Karaim with many Kipchak elements.

\section{Sample}

Hey adam oğlu ne uçun yuhlarsın | Aç gözüñi baq, balçıq topraqsın | Nece yaşarsiñ bir gün göçersin | Binyatıñ yoqdır adam oğlanı 'Why are you sleeping, man's son | Open your eyes, your are from clay and soil | However long you will live, you will pass away one day | You have no support' (Aqtay 2009, p. 102).

\section{Eliyahu Qazaz ${ }^{24}$}

Le-regel ha-jeladim 'Textbook for children' (Odessa, 1869); this is a Hebrew textbook for children consisting of lessons, a chrestomathy and a Hebrew-Karaim dictionary (Poznański 1913, p. 43, Walfish 2003, p. 939, Jankowski 2012, p. 60).

\section{Samples}

Ögüzi kim çaldı? 'Who has stolen the ox?'; atnı kim çaldı? 'who has stolen the horse?'; bügün bahçaya kim gitdi? 'who went to the garden today?' (p. 4).

\footnotetext{
${ }^{24}$ Eliyahu Qazaz (1833-1912) studied as a pupil of Abraham Łucki and Oriental studies in St. Petersburg (El'jaševič 1993, p. 79).
} 
Word order is frequently copied from Hebrew, e.g. babam satdl at 'my father has sold a horse' $\leftarrow$ Heb. אָבְי מָכָר סוּס

\section{Conclusion}

Due to unavailability of many Karaite printings it is premature to draw the final conclusion. For instance, works of such Karaite writers and activists as Firkovich's son Jacob, his grandson Moses, Samuel Pigit and some others must be examined. Nevertheless a general tendency to write in Crimean Turkish mixed with many Crimean Kipchak features is evident. This tendency is clear when we look at the Łucki family who moved to the Crimea. While the founder of the Crimean branch of this family, Simha Isaac b. Moses Łucki - if the attribution of Targum selihot to him is correct translated Hebrew works into Crimean Kipchak Karaim, close to his Łuck Karaim, his son Joseph Solomon preferred Turkish with Kipchak elements; Joseph Solomon's son, in turn, Abraham preferred a language very similar to standard Turkish.

\section{Abbreviations}

CKKar - Crimean Kipchak Karaim

HKar - Halicz Karaim

TKar - Troki Karaim

\section{References}

Aqtay, G. (2009): Eliyahu ben Yosef Qulcl's Anthology of Crimean Karaim and Turkish Literature. Critical Edition with Introduction, Indexes and Facsimile. Vols I-II. Istanbul, Mehmet Ölmez (Yıldız Dil ve Edebiyat Dizisi 8).

Doerfer, G. (1959a): Das Krimosmanische. In: Deny, J.-Grønbech, K.-Scheel, H.-Togan, Z. V. (eds): Philologiae Turcicae Fundamenta. Vol. 1. Wiesbaden, F. Steiner, pp. 272-280.

Doerfer, G. (1959b): Das Krimtatarische. In: Deny, J.-Grønbech, K.-Scheel, H.-Togan, Z. V. (eds): Philologiae Turcicae Fundamenta. Vol. 1. Wiesbaden, F. Steiner, pp. 369-390.

Dubiński, A. (1960): Z dziejów badań nad językiem i literaturą karaimską (do końca XIX wieku) [On the history of studying the Karaim language and literature (by the end of the 19th century)]. Przeglad Orientalistyczny No 2 (34), pp. 145-156.

El'jaševič, B. S. (1993): Karaimy. Kniga 2. Karaimskij bibliografičeskij slovar' (ot konca VIII v. do 1960 g.). Moskva, Institut Ètnologii im. N. N. Mikluho-Maklaja.

Gordlevskij, V. A. (1928): Leksika karaimskogo perevoda Biblii. La lexique de la traduction de la Bible Karaïme. Doklady Akademii nauk SSSR Vol. 5, pp. 87-91.

Günay, T. (2003): Rize İli A ğzı (İnceleme-Metinler-Sözlük) [The dialect of Rize Province. Studytexts-index]. Ankara, Türk Dil Kurumu. (2nd edition.)

Harviainen, T. (2003): Abraham Firkovich. In: Polliack, M. (ed.): Karaite Judaism. A Guide to Its History and Literary Sources. Leiden-Boston, Brill, pp. 875-892. 
Jankowski, H. (1997): A Bible Translation into the Northern Crimean Dialect of Karaim. Studia Orientalia Vol. 28, pp. 1-84.

Jankowski, H. (2003): On the Language Varieties of Karaims in the Crimea. Studia Orientalia Vol. 95, pp. $109-130$.

Jankowski, H. (2009): Translations of the Bible into Karaim. Religion Compass Vol. 3, No. 4, pp. $502-523$.

Jankowski, H. (2012): Literatura krymskokaraimska [Crimean Karaim literature]. Przeglad Orientalistyczny Nos 1-2, pp. 50-68.

Jankowski, H. (2013): Karaim mejumas in Eupatoria. In: Pang, T.-Raschmann, S.-Ch.-Winkelhane, G. (eds): Unknown Treasures of the Altaic World in Libraries, Archives and Museums. 53rd Annual Meeting of the Permanent International Altaistic Conference, Institute of Oriental Manuscripts, RAS St. Petersburg, July 25-30, 2010. Berlin, Klaus Schwarz Verlag, pp. $245-262$.

Jankowski, H. (2014): Two Karaim Religious Poems by Isaac ben Abraham Troki. Karaite Archives Vol. 2, pp. 35-57.

KRPS = Baskakov, N. A. -Zajončkovskij, A. - Šapšal, S. M. (eds) (1974): Karaimsko-pol'skorusskij slovar'. Moskva, Russkij Jazyk.

Kupoveckij, M. S. (1983): Dinamika čislennosti i rasselenie karaimov i krymčakov za poslednie dvesti let. In: Arutjunov, S. A. - Jerenkov, L. N. (eds): Geografija i kul'tura ètnografičeskih grupp tatar v SSSR. Dinamika, metody izučenija. Moskva, Moskovskij Filial Geografičeskogo Obščestva SSSR, pp. 75-93.

Mardkowicz, A. (1935): Karaj sez-bitigi. Stownik karaimski. Karaimisches Wörterbuch. Łuck.

Musaev, K. M. (1964): Grammatika karaimskogo jazyka. Fonetika i morfologija. Moskva, Nauka.

Musaev, K. M. (1977): Kratkij grammatičeskij očerk karaimskogo jazyka. Moskva, Nauka.

Musaev, K. M. (2003): Sintaksis karaimskogo jazyka. Moskva, Rossijskaja Akademija Nauk, Institut Jazykoznanija.

Németh, M. (2011): Unknown Lutsk Karaim Letters in Hebrew Script (19th-20th Centuries). A Critical Edition. Cracow (Studia Turcologica Cracoviensia 12).

Németh, M. (2014): An Early North-western Karaim Bible Translation from 1720. Part 1. The Torah. Karaite Archives Vol. 2, pp. 109-140.

Olach, Zs. (2013): A Halicz Karaim Translation of Hebrew Biblical Texts. Wiesbaden, Harrassowitz Verlag (Turcologica 98).

Poznański, S. (1913): Karäisch-tatarische Literatur. Keleti Szemle Vol. 13, pp. 37-47.

Poznanski, S. (1916): Karäische Kopisten und Besitzer von Handschriften. Zeitschrift für Hebräische Bibliographie Vol. 19, pp. 79-122.

Poznanski, S. (1918-1920): Karäische Drucke und Druckereien. Zeitschrift für Hebräische Bibliographie Vol. 21 (1918), pp. 32-48; pp. 66-83; Vol. 23 (1920), pp. 65-68.

Pritsak, O. (1959): Das Karaimische. In: Deny, J. - Grønbech, K. - Scheel, H. - Togan, Z. V. (eds): Philologiae Turcicae Fundamenta. Vol. 1. Wiesbaden, Steiner, pp. 318-340.

Radloff, W. (1896): Proben der Volkslitteratur der Nördlichen Türkischen Stämme. Theil VII. Die Mundarten der Krym. Mäğuma ya 'ni Qïrümdagïi Qara’imlar arasïnda qollanġan mäsälilär, hikayätlär, zarpu mäsälilär vä tapmağalar [Mejuma or tales, stories, proverbs and riddles recited by the Crimean Karaims]. St. Petersburg.

Samojlovič, A. N. (2000): O materialah Radlova po slovesnosti krymskih tatar i karaimov. In: Samojlovič, A. N.: Izbrannye trudy o Kryme. Simferopol, Dolja, pp. 112-121. (Re-edited from 1917.) 
Shapira, D. (2003): The Turkic Languages and Literatures of the East European Karaites. In: Polliack, M. (ed.): Karaite Judaism. A Guide to its History and Literary Sources. Leiden-Boston, Brill, pp. 657-707.

Shapira, D. (2013): The Karaim Translation of the Book of Nehemia Copied in the 17th Century's Crimea and Printed in 1840/1841 at Gözleve, on the Copyist of the Manuscript, and Some Related Issues. Karaite Archives Vol. 1, pp. 133-198.

Shapira, D. (2014): A New Karaite-Turkish Manuscript from Germany: New Light on Genre and Language in Karaite and Rabbanite Turkic Bible Translations in the Crimea, Constantinople and Elsewhere. Karaite Archives Vol. 2, pp. 143-176.

Smętek, D. (2012): Crimean Karaim Version of Melukhat Sha'ul. Critical Edition and Linguistic Analysis. Poznań, Adam Mickiewicz University. (Unpublished doctoral dissertation.)

Sulimowicz, J. (1972): Materiał leksykalny krymskokaraimskiego zabytku językowego (druk z 1734 r.). I [Lexical material of the Crimean Karaim document printed in 1734. Part I]. Rocznik Orientalistyczny Vol. 35, No. 1, pp. 37-76.

Sulimowicz, J. (1973): Materiał leksykalny krymskokaraimskiego zabytku językowego (druk z 1734 r.). II [Lexical material of the Crimean Karaim document printed in 1734. Part II]. Rocznik Orientalistyczny Vol. 36, No. 1, pp. 47-107.

Šapšal, S. (1918): Kratkij očerk" tjurksko-karaimskoj literatury. Izvěstìja Karaimskago Duhovnago Pravlenija Vol. 1, pp. 6-10; Vol. 2, pp. 13-17.

Walfish, B. D. (2003): Karaite Press and Printing. In: Polliack, M. (ed.): Karaite Judaism. A Guide to its History and Literary Sources. Leiden-Boston, Brill, pp. 925-959.

Wexler, P. (1983): Is Karaite a Jewish Language? Mediterranean Language Review Vol. 1, pp. $27-54$.

Zajączkowski, A. (1926): Literatura karaimska (Szkic bibliograficzny) [Karaim literature (A bibliographic outline)]. Myśl Karaimska Vol. 1, No. 3, pp. 7-17.

Zajączkowski, A. (1961): Karaims in Poland. History, Language, Folklore, Science. Warsaw-La Haye, Polskie Wydawnictwo Naukowe-Mouton.

Zajączkowski, A. (1964): Die karaimische Literatur. In: Bazin, L. - Bombac1, A. - Deny, J. -Gökbilgin, T. - İz, F. - Scheel, H. (eds): Philologiae Turcicae Fundamenta. Vol. 2. Wiesbaden, Franz Steiner, pp. 793-801. 